\title{
DINAMIKA DAN KESESUAIAN ARAHAN FUNGSI KAWASAN DI KOTA DENPASAR
}

\section{Gusti Putu Desya Surya Pratiwi ${ }^{1}$, I Putu Ananda Citra ${ }^{2 *}$}

Prodi Pendidikan Geografi, Universitas Pendidikan Ganesha, Indonesia

\section{A R TICLEINFO}

\section{Article history:}

Received 19 Januari 2019

Received in revised form

6 Februari 2019

Accepted 12 Maret 2019

Available online 31 Maret 2019

\section{Kata Kunci: arahan fungsi}

kawasan; penggunaan

lahan; Kota Denpasar

Keywords:

the instruction of functional area, land use, dynamic,

Denpasar City

\begin{abstract}
ABSTRAK
Penelitian ini dilakukan di Kota Denpasar dengan tujuan: mendeskripsikan dinamika spasial penggunaan lahan di Kota Denpasar dan menganalisis kesesuaian arahan fungsi kawasan terhadap penggunaan lahan di Kota Denpasar. Populasi penelitian adalah seluruh penggunaan lahan di Kota Denpasar yang terdiri dari 4 kecamatan yaitu Denpasar Utara, Denpasar Timur, Denpasar Barat dan Denpasar Selatan. Datadi kumpulkan dengan cara menginterpretasi citra landsat 8 yang diperoleh dari Usgs.gov. Hasil penelitian (1) Dinamika penggunaan lahan di Kota Denpasar pada tahun 2014 dan tahun 2017 adalah sebesar 1906.14 Ha atau 15.699 $\%$. Perubahan penggunaan lahan lebih dominan terjadi pada penggunaan lahan bangunan industri/perdagangan dan jasa dengan luasan masing-masing $46.07 \mathrm{Ha}$ pada tahun 2014 meningkat menjadi 287.47 Ha pada tahun 2017 yang mengalami peningkatan sebesar $241.4 \mathrm{Ha}$ atau 1.988 \%. (2) Kesesuaian arahan fungsi kawasan lebih dominan sesuai dengan penggunaan lahan Kota Denpasar tahun 2017 dengan luas $77.779 \%$ dan yang tidak sesuai dengan luas $22.221 \%$.
\end{abstract}

\section{A B STRACT}

This research was conducted in Denpasar for some following objectives: (The populations for this study were all the land use in the Denpasar City which are consists of 4 districts named North Denpasar, East Denpasar, West Denpasar, and South Denpasar.. The results of this study were (1) The dynamics of land use in Denpasar City in 2014 and 2017 is $1906.14 \mathrm{Ha}$ or $15,699 \%$. Land use change is more dominant in industrial / trade and service building land use with an area of $46.07 \mathrm{Ha}$ in 2014 increased to $287.47 \mathrm{Ha}$ in 2017 which increased by $241.4 \mathrm{Ha}$ or 1,988\%. However, (2) Suitability landing more dominant function of the area in accordance with the land use of Denpasar City in 2017 with an area of $77779 \%$ and that does not comply with an area $22221 \%$.

\footnotetext{
* Corresponding author.

E-mail addresses: suryadesya@gmail.com, ananda.citra@undiksha.ac.id
} 


\section{Pendahuluan}

Kota merupakan daerah permukiman yang sifatnya sangat dinamis, baik ditinjau dari segi sosial, ekonomi, kultural maupun spasialnya. Terdapat dua faktor utama yang dikenal sebagai determinan sifat dinamika kehidupan kota yang sangat tinggi tersebut, yaitu faktor kependudukan di satu sisi dan faktor kegiatan penduduk di sisi yang lain (Yunus, 2005). Fenomena yang terjadi adalah penggunaan lahan yang terus mengalami perubahan seiring dengan bertambahnya kebutuhan manusia. Peralihan penggunaan lahan tertentu menjadi penggunaan untuk fungsi lainnya menunjukkan bahwa semakin tinggi kebutuhan manusia maka semakin tinggi pula kebutuhan akan lahan (Maulana dan Rudiarto, 2016). Pertambahan penduduk kota yang terus menerus dan masih tergolong tinggi ini, membawa konsekuensi spasial yang serius bagi kehidupan kota, yaitu adanya tuntutan akan ruang yang terus menerus untuk dimanfaatkan sebagai tempat hunian.

Pertumbuhan penduduk perkotaan saat ini mengakibatkan kebutuhan akan lahan meningkat (Prihatin, 2015). Salah satu provinsi yang tengah mengalami pertumbuhan jumlah penduduk adalah Provinsi Bali. Pertumbuhan penduduk di Provinsi Bali disebabkan adanya migrasi penduduk dan juga pertumbuhan alami. Daerah asal migran yang menuju Bali tersebar dari berbagai provinsi di Indonesia, namun yang paling menonjol adalah migran yang berasal dari Jawa Timur. Banyak faktor yang menentukan migran asal Jawa Timur yang menuju Bali antara lain karena jaraknya yang relatif dekat, tersedianya fasilitas sarana dan prasarana transportasi antara Jawa Timur dan Bali yang sangat memadai serta faktor lainnya (Sudibia dkk, 2012). Faktor lainnya adalah Provinsi Bali dikenal sebagai provinsi yang memiliki daya tarik wisata, sehingga perkembangan untuk jasa penunjang pariwisata di Bali setiap tahunnya meningkat. Seperti peningkatan jumlah hotel di Bali pada tahun 2006 berjumlah 1.653 hotel dan meningkat pada tahun 2016 menjadi 4.880 hotel (Tribun-Bali, 2017). Jumlah penduduk Provinsi Bali sebanyak 3.890.757 jiwa yang mencakup mereka yang bertempat tinggal di daerah perkotaan sebanyak 2.342 .579 jiwa $(60,21 \%)$ dan di daerah perdesaan sebanyak 1.548 .178 jiwa $(39,79 \%)$. Persentase distribusi penduduk menurut kabupaten/kota bervariasi dari yang terendah sebesar 4,38 \% di Kabupaten Klungkung hingga yang tertinggi sebesar 20,27 \% di Kota Denpasar (BPS, 2017). Kota Denpasar merupakan salah satu kota yang mengalami perkembangan yang dinamis, baik itu dari pembangunan maupun perkembangan penduduknya. Menurut BPS Kota Denpasar Tahun 2017, jumlah penduduk di Kota Denpasar berdasarkan hasil sensus tahun 2010 adalah 788.589 jiwa dengan luas wilayah $127,78 \mathrm{~km}^{2}$ dengan kepadatan penduduk sebanyak 6.171 per $\mathrm{km}^{2}$.

Pertumbuhan jumlah penduduk mengakibatkan semakin meningkatnya permintaan akan ruang khususnya untuk permukiman dan lahan terbangun akan berdampak kepada semakin merosotnya kualitas lingkungan. Penggunaan lahan yang belum sesuai dengan arahan fungsi kawasan menyebabkan permasalahan akan pelanggaran tata guna lahan terjadi, baik itu permasalahan lingkungan maupun permasalahan sosial. Berkembangnya lahan terbangun yang memanfaatkan lahan produktif, seperti lahan sawah dan tegalan dijadikan kawasan permukiman dan pertokoan serta memanfaatkan ruang pekarangan rumah masyarakat adat cenderung mulai meninggalkan konsepsi tata ruang tradisional Bali dan munculnya tata ruang baru yang berorientasi ekonomi (Wesnawa, 2010).Hal ini terjadi pada ruang terbuka hijau di seluruh kecamatan di Kota Denpasar. Balipost memberitakan pada tahun 2012 bahwa pelanggaran terbanyak terjadi di kawasan Denpasar Barat dan Kecamatan Denpasar Utara. Wilayah itu meliputi kawasan Panjer, Renon, Jalan Gatot Subroto dan Ubung. Denpasar Barat sendiri memiliki RTH 524,20 hektar dari luas wilayah 2.413 hektar. Sementara RTH di wilayah Denpasar Utara seluas 1.042 hektar dari luas wilayah 3.112 hektar.

Menurut Badan Perencanaan dan Pembangunan Daerah Kota Denpasar, Kota Denpasar memiliki 2 arahan kawasan yaitu kawasan lindung dan kawasan budidaya. Kawasan lindung lebih dominan berada di Kecamatan Denpasar Selatan dan kawasan budidaya berada di hampir setiap kecamatan. Namun kawasan budidaya untuk Hutan Kota lebih dominan berada di Kecamatan Denpasar Utara dan Denpasar Timur. Hal tersebut dikarenakan di Kecamatan Denpasar Utara dan Kecamatan Denpasar Timur lahan persawahan masih ada dan dilestarikan sebagai tempat wisata seperti yang ada di Desa Peguyangan yaitu mengembangankan lahan persawahan sebagai ekowisata. Pemerintah Kota Denpasar sudah merencanakan rencana mengenai arahan fungsi kawasan. Seperti kawasan lindung yang diarahkan seluas 1.200,1 Ha atau 8,39 \% dan kawasan budidaya diarahkan seluas 11.577,9 atau 90,61\%.

Penelitian yang dilakukan oleh Achmad dkk tahun 2015 yang berjudul "Strategi Penentuan Lokasi dan Kebutuhan Lahan TPS Berdasarkan Fungsi Kawasan di Kota Denpasar" dan Simamora dkk pada tahun 2011 menyatakan bahwa kebutuhan akan lahan masih sangat tinggi di Kota Denpasar dan masih terdapat pelanggaran yang terjadi terhadap penggunaan lahan yag ada. Perubahan yang paling dominan terjadi di Kecamatan Denpasar Barat sebesar 6261,740 Ha dan Denpasar Utara sebesar 
2164,490 Ha. Adanya fenomena tersebut maka perlu dilakukan evaluasi penggunaan lahan yang ada terhadap arahan fungsi kawasan. Tujuannya adalah untuk mengurangi risiko terjadinya ketidaksesuaian lahan terhadap arahan fungsi kawasan yang ada di Kota Denpasar. Identifikasi lahan dilakukan untuk mengetahui apakah penggunaan lahan yang ada sudah sesuai dengan arahan fungsi kawasan atau belum dengan cara menganalisis citra satelit yang ada selama 3 tahun terakhir. Berdasarkan permasalahan tersebut maka menarik untuk dikaji tentang dinamika perubahan penggunaan lahan kota dan kesesuaian arahan fungsi kawasan di Kota Denpasar.

\section{Metode}

Penelitian ini dirancang sebagai penelitian deskriptif dengan pendekatan keruangan pada tema pola keruangan.Pendekatan yang digunakan yaitu keruangan pada tema pola keruangan karena penelitian ini memiliki gejala yang kompleks. Untuk mengukur kompleksitas tersebut maka diperlukan peta untuk melihat gejala-gejala yang ada di permukaan bumi (Yunus, 2010). Dalam penelitian ini yang dideskripsikan adalah (1) variasi dinamika perubahan penggunaan lahan pada masing-masing kecamatan di Kota Denpasar dan (2) kesesuaian arahan fungsi kawasan terhadap penggunaan lahan di Kota Denpasar. Penelitian ini dilaksanakan di Kota Denpasar.

Populasi dalam penelitian ini seluruh penggunaan lahan yang ada di seluruh kecamatan yang ada di Kota Denpasar yang terdiri dari 4 kecamatan. Penelitian ini merupakan penelitian populasi sehingga tidak menggunakan sampel. Sumber data berasal dari BPS Kota Denpasar yang berupa jumlah penduduk Kota Denpasar beserta luas wilayah Kota Denpasar dan Usgs.gov berupa data citra landsat 8 untuk mengetahui penggunaan lahan di Kota Denpasar.

Adapun metode pengumpulan data yang dilakukan pada penelitian ini yaitu observasi, interpretasi citra satelit dan pencatatan dokumen. Ketiga metode pengumpulan data tersebut dilakukan secara alami tanpa perlakukan khusus terlebih dahulu. Instrumen yang digunakan dalam penelitian ini berupa pedoman untuk melakukan interpretasi citra satelit untuk mengetahui objek yang terdapat pada citra sehingga mudah untuk diidentifikasikan. Data yang sudah terkumpul kemudian diolah menggunakan aplikasi ENVI dan ArcGis untuk mengetahui penggunaan lahan yang ada di Kota Denpasar kurun waktu 2014 dan 2017.

\section{Hasil Dan Pembahasan}

\subsection{Dinamika Spasial Penggunaan Lahan di Kota Denpasar}

Penggunaan lahan di suatu wilayah setiap tahunnya pasti akan mengalami perubahan, terutama di wilayah perkotaan. Salah satunya adalah Kota Denpasar yang merupakan ibukota Provinsi Bali. Penggunaan lahan di Kota Denpasar mengalami perubahan setiap tahunnya karena wilayah perkotaan yang sifatnya dinamis. Hasil penelitian mengidentifikasikan penggunaan lahan yang ada di Kota Denpasar dari tahun 2014 - 2017 seperti terlihat pada Tabel 1.

Tabel 1

Data Penggunaan Lahan di Kota Denpasar Tahun 2014 dan tahun 2017

\begin{tabular}{|c|c|c|c|c|c|}
\hline \multirow{3}{*}{ No } & \multirow{3}{*}{ Penggunaan Lahan } & \multicolumn{2}{|c|}{ Tahun } & \multirow{3}{*}{$\begin{array}{c}\text { Perubahan } \\
\text { penggunaan lahan }\end{array}$} & \multirow{3}{*}{$\%$} \\
\hline & & \multicolumn{2}{|c|}{2014} & & \\
\hline & & Total (Ha) & Total (Ha) & & \\
\hline 1 & Permukiman & 4526.04 & 4303.62 & 222.42 & 1.831 \\
\hline 2 & $\begin{array}{l}\text { Industri/Perdagangan dan } \\
\text { jasa }\end{array}$ & 46.07 & 287.47 & 241.4 & 1.988 \\
\hline 3 & Hutankota/bakau & 948.49 & 769.95 & 178.54 & 1.470 \\
\hline 4 & Sawah & 1543.84 & 1280.21 & 263.63 & 2.171 \\
\hline 5 & Lahan terbuka & 597.73 & 309.26 & 288.47 & 2.375 \\
\hline 6 & Penggunaan lahan lainnya & 4479.24 & 5190.92 & 711.68 & 5.861 \\
\hline & Total & 12141.41 & 12141.41 & 1906.14 & 15.699 \\
\hline
\end{tabular}

Tabel 1 menunjukkan penggunaan lahan di Kota Denpasar pada tahun 2014 dan 2017. Penggunaan lahan di Kota Denpasar telah mengalami perubahan dari tahun 2014 sampai dengan 2017 dengan total perubahan sebesar 15.699 \%. Penggunaan lahan yang paling dominan pada tahun 2014 dan 
2017 adalah permukiman dengan luas 4526.04 Ha pada tahun 2014 dan 4303.62 Ha pada tahun 2017. Perubahan penggunaan lahan yang paling dominan adalah komplek perumahan menjadi bangunan/gedung. Penggunaan lahan yang cenderung terus mengalami peningkatan adalah bangunan industri/perdagangan dan jasa dengan luasan masing-masing yaitu 46.07 Ha pada tahun 2014 meningkat menjadi $287.47 \mathrm{Ha}$ pada tahun 2017 yang mengalami peningkatan sebesar $241.4 \mathrm{Ha}$ atau $1.988 \%$. Penggunaan lahan sawah dan juga hutan bakau mengalami penurunan pada kurun waktu 2014 - 2017. Penggunaan lahan sawah mengalami penurunan dari 1543.84 Ha menjadi 1280.21 Ha dengan perubahan sebesar $263.63 \mathrm{Ha}$ atau $2.171 \%$. Penggunaan lahan hutan bakau (hutan konservasi) mengalami penurunan dari 948.49 Ha menjadi 769.95 Ha dengan perubahan sebesar $178.54 \mathrm{Ha}$ atau $1.470 \%$. Penggunaan lahan terbuka mengalami penurunan dari 597.73 Ha menjadi 309.26 Ha dengan perubahan sebesar 288.47 atau $2.375 \%$.

Perubahan struktur penggunaan lahan bukanlah semata-mata fenomena fisik berkurangnya luasan lahan tertentu dan meningkatnya penggunaan lahan untuk penggunaan lainnya, melainkan mempunyai kaitan erat dengan perubahan orientasi ekonomi, sosial, budaya dan politik masyarakat. Perubahan orientasi tersebut berkait dengan terjadinya proses transformasi struktur perekonomian yang dicirikan semakin menurunnya pangsa relatif sektor primer (pertanian dan pertambangan) dan semakin meningkatnya pangsa relatif sektor sekunder dan tersier (industri dan jasa). Dengan demikian pembangunan ekonomi diarahkan untuk mengurangi ketergantungan perekonomian suatu wilayah terhadap sektor primer yang mempunyai nilai tambah (value added) yang lebih rendah dibandingkan dengan sektor sekunder dan tersier (Utoyo, 2012). Penggunaan lahan di Kota Denpasar mengalami perubahan setiap tahunnya, hal tersebut disebabkan karena wilayah perkotaan yang bersifat dinamis yang disebabkan oleh faktor kependudukan dan juga ativitas penduduk.

Berdasarkan Tabel 1.2 terlihat bahwa setiap penggunaan lahan mengalami perubahan. Penggunaan lahan yang terlihat paling dominan adalah permukiman yang disebabkan karena yang mempengaruhi dinamika wilayah perkotaan adalah penduduknya, sehingga kebutuhan akan ruang juga semakin meningkat. Perubahan penggunaan lahan di Kota Denpasar sesuai dengan hasil penelitian yang dilakukan oleh Simamora (2012) yang juga menyatakan bahwa penggunaan lahan di Kota Denpasar mengalami perubahan dari tahun 2007 dan 2011. Berdasarkan rentangan waktu tersebut perubahan penggunaan lahan di tiap kecamatan di Kota Denpasar yaitu sebesar 1906.14 Ha atau 15.699 \%. Penambahan luasan bangunan industri/perdagangan dan jasa dipengaruhi oleh penambahan jasa pariwisata yang ada di Kota Denpasar. Berdasarkan Tabel 4.6 lapangan pekerjaan yang paling dominan di Kota Denpasar adalah perdagangan, usaha rumah makan dan hotel. Faktor lainnya yang mempengaruhi maraknya pembangunan bangunan industri/perdagangan dan jasa adalah karena Kota Denpasar merupakan Ibukota Provinsi Bali, Kota Denpasar juga merupakan satu-satunya Kota Madya yang ada di Provinsi Bali. Dengan statusnya tersebut, Kota Denpasar memiliki berbagai macam daya pikat, seperti lapangan pekerjaan yang menjanjikan serta wilayah yang strategis dengan tempat tujuan wisata seperti dekat dengan Kabupaten Badung, Gianyar dan Tabanan. Pendatang yang datang ke Kota Denpasar berasal dari seluruh kabupaten yang ada di Bali dan di tambah oleh imigran asal luar Bali. Wilayah perkotaan memang menjadi pusat dari berbagai kegiatan pembangunan, mulai dari perdagangan, industri sampai dengan administrasi dan pembangunan politik, sehingga menjadi daya tarik yang kuat bagi penduduk dari daerah-daerah lain. Perkotaan menyediakan kesempatan kerja dan usaha ekonomi di berbagai bidang, sementara di daerah asal mereka menghadapi keterbatasan kesempatan ekonomi. Perpindahan penduduk terjadi akibat tingginya upah yang dapat diperoleh di daerah tujuan. Seperti halnya Kota Denpasar yang maju dalam segala bidang, baik itu bidang pendidikan, kesehatan, ekonomi, jasa dan lain sebagainya. Faktor-faktor tersebut yang dapat mempengaruhi semakin bertambahnya jumlah bangunan industri/perdagangan dan jasa di Kota Denpasar.

Perubahan penggunaan lahan sawah disebabkan adanya alih fungsi lahan dari lahan sawah ke lahan permukiman, lahan terbuka maupun menjadi bangunan industri/perdagangan dan jasa. Perubahan penggunaan lahan hutan bakau (hutan konservasi) ini diakibatkan oleh tanaman bakau yang mati karena adanya pencemaran di sekitar wilayah hutan bakau ini. Berdasarkan observasi yang dilakukan dapat dilihat bahwa terdapat tanaman bakau yang mati dan tidak bisa berkembang dengan baik dikarenakan oleh tumpukan sampah yang berada di sekitar habitat hutan bakau ini hidup. Faktor lainnya yang menyebabkan hutan bakau tercemar yaitu akibat sampah kiriman karena hutan bakau berada pada hilir sungai di Kota Denpasar yang membuat didalam hutan bakau banyak sampah yang tertimbun dan kurangnya kesadaran pengunjung taman wisata bakau yang membawa makanan kedalam taman wisata dan membuang sisa pembungkus makanan ke rawa-rawa hutan, hutan bakau tercemar oleh sampah yang dibuang sembarangan oleh pengunjung wisata. Terkait dengan isu lingkungan penulis melihat ini sebagai dampak yang ditimbulkan dari perilaku manusia yang tidak sadar terhadap pentingnya lingkungan bagi 
kehidupan. Selain itu berkurangnya tanaman bakau ini adalah dekatnya wilayah konservasi dengan TPA (tempat pembuangan akhir) Suwung yang mengakibatkan banyaknya sampah yang masuk ke hutan bakau ini. Penurunan ini diakibatkan oleh lahan terbuka yang beralih fungsi menjadi penggunaan lahan lainnya seperti permukiman dan bangunan industri/perdagangan dan jasa lainnya. Penggunaan lahan lainnya yaitu penggunaan lahan yang tidak teridentifikasikan sebagai fungsi kawasan. Penggunaan lahan lainnya terdiri dari jalan, sungai, garis pantai dan lain sebagainya.

\subsection{Kesesuaian Arahan Fungsi Kawasan dengan Penggunaan Lahan}

Kota Denpasar memiliki 2 fungsi kawasan yaitu kawasan lindung dan kawasan budidaya yang tercantum dalam rencana pola ruang wilayahnya yang sudah direncanakan dari tahun 2011 - 2031. Pada penelitian ini akan dilihat kesesuaian rencana pola ruang wilayah dengan penggunaan lahan pada tahun 2017. Proses untuk menentukan apakah peta rencana pola ruang wilayah Kota Denpasar dengan penggunaan lahan pada tahun 2017 adalah dengan cara melakukan overlay kedua peta tersebut. Berdasarkan hasil analisis data hasil overlay peta rencana pola ruang wilayah Kota Denpasar dengan peta penggunaan lahan pada tahun 2017 didapatkan hasil yang mendominasi adalah kawasan sesuai dengan luas $9443.393 \mathrm{Ha}$ atau 77.779 \% dan kawasan tidak sesuai dengan luas 2697.916 Ha atau $22.221 \%$. Rincian penggunaan lahan yang sesuai dan tidak sesuai dapat dilihat pada Tabel 2.

Tabel 2 Penggunaan lahan Kota Denpasar tahun 2017 dengan RPRW

\begin{tabular}{lll} 
& \multicolumn{1}{c}{ So } & \multicolumn{1}{c}{ Tidak Sesuai } \\
\hline 1 & Permukiman & $\begin{array}{l}\text { Industri/perdagan } \\
\text { gan dan jasa }\end{array}$ \\
\hline 2 & RTH (Sawah) & Permukiman \\
\hline 3 & Hutan kota & - \\
\hline 4 & $\begin{array}{l}\text { Sempadan } \\
\text { sungai }\end{array}$ & - \\
\hline 5 & Sempadan panta & -
\end{tabular}

Rencana Pola Ruang Wilayah Kota Denpasar Tahun 2011-2031 yang dimaksud adalah fokus wilayah yang dikaji yaitu mengenai arahan fungsi kawasan yang terdapat dalam rencana pola ruang wilayah Kota Denpasar. Arahan fungsi kawasan yang di rencanakan oleh Pemerintah Kota Denpasar terdapat 2 arahan fungsi kawasan yaitu kawasan lindung dan kawasan budidaya. Kawasan lindung terdiri dari penggunaan lahan taman hutan raya, sempadan sungai dan juga sempadan pantai, sedangkan kawasan budidaya terdiri dari permukiman, perdagangan dan jasa, kantor pemerintahan, pendidikan, akomodasi pariwisata, ruang terbuka hijau, lapangan olahraga, industri, fasilitas kesehatan, setra dan kuburan, terminal, IPAL, TPA, pura/kawasan suci, pelabuhan laut, DTW pesisir, hutan kota, estuary DAM dan redarding basin. Berdasarkan hasil overlay peta rencana pola ruang wilayah Kota Denpasar dengan peta penggunaan lahan Kota Denpasar tahun 2017 didapatkan hasil yang mendominasi adalah daerah yang sesuai. Hal tersebut terlihat bahwa penggunaan lahan ruang terbuka hijau (sawah) masih dijaga kelestariannya terutama di Kecamatan Denpasar Utara dan Timur. Hal tersebut dibuktikan dengan dijadikannya lahan persawahan tersebut sebagai ekowisata oleh pemerintah kota. Selain 2 kecamatan tersebut di Kecamatan Denpasar Selatan juga terdapat hutan konservasi yaitu hutan bakau yang juga dijadikan sebagai salah satu destinasi wisata yang menarik, sehingga dengan langkah-langkah menjadikan sawah dan hutan konservasi sebagai destinasi pariwisata maka hal tersebut dapat menjaga peruntukan penggunaan lahan tersebut sehingga luas RTH untuk daerah perkotaan sebesar $30 \%$ dapat terpenuhi. Pada situs resmi Kota Denpasar, Pemerintah Kota Denpasar juga rutin mengadakan seminar terkait dengan kelestarian subak di Kota Denpasar. Seminar ini bertujuan untuk mempertahankan eksistensi subak dengan menekan alih fungsi lahan dalam upaya meningkatkan produksi dan produktifitas pertanian khususnya Kota Denpasar serta mampu memberikan nilai tambah kepada petani. Namun tidak dapat dipungkiri alih fungsi lahan secara illegal juga masih marak terjadi di Kota Denpasar. Lahan persawahan yang seharusnya merupakan ruang terbuka hijau dialih fungsikan menjadi permukiman atau bangunan industri/perdagangan dan jasa. Faktor yang mempengaruhinya adalah tuntutan akan ruang yang semakin meningkat dengan jumlah penduduk yang padat.

Penelitian serupa juga dilakukan oleh Ahmad Duri pada tahun 2016 di Kabupaten Pati dengan hasil lebih dominan penggunaan lahan yang sesuai dengan arahan fungsi kawasan jika dibandingkan dengan penggunaan yang tidak sesuai. Faktor yang mempengaruhi yaitu penggunaan lahan yang tidak sesuai dengan karakteristik fisik setiap fungsi kawasan yang ada. Namun faktor lain yang dapat 
mempengaruhi juga adalah aktivitas manusia itu sendiri. Hal yang dikhawatirkan dari ketidaksesuaian tersebut adalah ketidakmampuan fisik setiap kawasan menopang berbagai jenis penggunaan lahan yang ada, sehingga dapat menimbulkan kerugian bagi lingkungan dan masyarakat, bahkan dapat berpotensi bencana. Perlunya tindakan atau memberikan solusi untuk merelokasi penggunaan lahan yang ada bagi pemerintah daerah sangat dibutuhkan. Solusi yang dapat diberikan untuk menanggapi ketidaksesuaian tersebut adalah dengan tetap memperhatikan pengelolaan penggunaan lahan yang sudah ada, serta membatasi aktivitas yang dinilai merugikan lingungan dan dapat mengurangi keseimbangan ekologi. Pencegahan agar ketidaksesuaian lahan tersebut tidak memberikan dampak yang lebih buruk baik bagi alam itu sendiri maupun masyarakat.

Penelitian yang dilakukan oleh Trigus dan Rahayu (2012)juga menyatakan bahwa dalam kaitan antara perubahan penggunaan lahan dan rencana pemanfaatan ruang diketahui bahwa persentase perubahan penggunaan lahan yang sesuai dengan rencana lebih besar daripada yang tidak sesuai yaitu sebesar 65,91\% berbanding 34,09\%. Besarnya persentase ketidak sesuaian ini mengindikasikan adanya suatu permasalahan dalam implementasi rencana pemanfaatan ruang. Dari analisis SWOT terhadap implementasi kebijakan rencana pemanfaatan ruang diketahui kelemahan terletak pada faktor/aspek peraturan yaitu belum disahkan dokumen RDTR APY Kecamatan Mlati menjadi Peraturan Daerah. Hal ini penting karena peraturan tersebut merupakan dasar hukum dari pelaksanaan rencana tata ruang. Tersedianya lembaga koordinasi dan pelaksana pengawasan dan pengendalian pemanfaatan ruang serta didukung dengan sumberdaya manusia yang mencukupi merupakan kekuatan pendukung implementasi. Pada faktor/aspek pelaksanaan, prosedur rencana, pengawasan dan pengendalian sudah dilakukan sesuai peraturan yang ada namun hal ini tidak diikuti dengan penindakan secara tegas terhadap pelanggaran rencana tata ruang. Lemahnya penegakan hukum dan pengendalian ini merupakan kelemahan pada aspek pelaksanaan. Hal yang bisa mengancam implementasi adalah investasi dan kebijakan pemerintah tentang peningkatan nilai pajak. Dari sisi masyarakat terdapat ketidaktahuan serta kenekatan masyarakat dalam melakukan pelanggaran pemanfaatan ruang. Kearifan lokal dan kesadaran masyarakat tentang pentingnya perijinan serta peran pemerintah desa merupakan peluang yang bisa digunakan dalam mengimplementasikan kebijakan rencana tata ruang.

\section{Simpulan Dan Saran}

Berdasarkan hasil penelitian dan pembahasan yang telah diuraikan, dapat disimpulkan beberapa hal-hal sebagai berikut. 1). Dinamika penggunaan lahan di Kota Denpasar pada tahun 2014 dan tahun 2017 adalah sebesar 1906.14 Ha atau 15.699\%. Perubahan penggunaan lahan lebih dominan terjadi pada penggunaan lahan bangunan industri/perdagangan dan jasa dengan luasan masing-masing 46.07 Ha pada tahun 2014 meningkat menjadi 287.47 Ha pada tahun 2017 yang mengalami peningkatan sebesar 241.4 Ha atau 1.988 \%. Namun secara keseluruhan penggunaan lahan di Kota Denpasar mengalami perubahan yang signifikan., 2). Kesesuaian arahan fungsi kawasan lebih dominan sesuai dengan penggunaan lahan Kota Denpasar tahun 2017 dengan luas 9443.393 Ha atau $77.779 \%$ dan yang tidak sesuai dengan luas $2697.916 \mathrm{Ha}$ atau $22.221 \%$.

Saran yang dapat disampaikan berdasarkan penelitian yang telah dilakukan, sebagai berikut. 1). Bagi Pemerintah Kota Denpasar, penelitian ini dapat djadikan salah satu masukan untuk merefleksikan diri untuk melakukan pembangunan sesuai dengan rencana tata ruang kota agar penggunaan lahan di Kota Denpasar bisa sesuai dengan rencana tata ruang wilayah yang telah di rencanakan. Agar masyarakat kota merasa lebih nyaman untuk melakukan aktivitasnya di daerah perkotaan 2). Bagi masyarakat, penelitian ini dapat dijadikan acuan sebagai arahan dan informasi kepada masyarakat agar memperhatikan kondisi fungsi lahan sehingga tidak terjadi kesalahan dalam pemanfaatan lahan dan melakukan pembangunan sesuai dengan peraturan pemerintah tentang rencana tata ruang wilayah.

\section{Daftar Rujukan}

Eko, Trigus dan Rahayu, S. (2012). Perubahan Penggunaan Lahan dan Kesesuaiannya terhadap RDTR di Wilayah Peri-Urban Study Kasus: Kecamatan Mlati. Jurnal Pembangunan Wilayah Kota, 8(4), 330340. Retrieved from https://s3.amazonaws.com/academia.edu.documents/43620172/6487-138751-SM.pdf?response-content-disposition=inline\%253B

filename\%253DPerubahan_Penggunaan_Lahan_dan_Kesesuaia.pdf\&X-Amz-Algorithm=AWS4HMAC-SHA256\&X-Amz-Credential=AKIAIWOWYYGZ2Y53UL3A\%252F20190911\%252

Karunia Kinantar Maulana, dan I. R. (2016). Kesesuaian Lahan dan Faktor-Faktor yang Mempengaruhi Implementasi Penataan Ruang di Sub Das Gunting Kabupaten Jombang. Jurnal Pembangunan 
Wilayah Kota, 11(2), 194-210.

Kusniarti, A. S. (2017). Jumlah Hotel di Bali Naik Jadi 2.079, Disparda dan PHRI Usulkan Moratorium.

Tribun-Bali. Retrieved from https://bali.tribunnews.com/2017/04/20/jumlah-hotel-di-bali-naikjadi-2079disparda-dan-phri-usulkan-moratorium?page=all

Prihatin, R. B. (2015). ALIH FUNGSI LAHAN DI PERKOTAAN. Jurnal DPR RI, 6(2), 2015.

Simamora, A. G. (2012). Analisis Perubahan Zona Nilai Tanah Akibat Perubahan Penggunaan Lahan di Kota Denpasar Tahun 2007 dan 2011. Universitas Diponegoro.

Sudibia, R. dan A. (2012). Pola Migrasi dan Karakteristik Migran dan Berdasarkan Hasil Sensus Penduduk 2010 di Provinsi Bali. PIRAMIDA, 3(2), 52-79.

Utoyo, B. (2012). Dinamika Penggunaan Lahan di Wilayah Perkotaan. Seminar Hasi-Hasil Penelitian Dan Pengabdian Kepada Masyarakat. Bandar Lampung.

Wesnawa, I. G. A. (2010). Dinamika Pemanfaatan Ruang Berbasis Kearifan Lokal di Kabupaten Buleleng Provinsi Bali. Forum Geografi, 1.

Yunus, S. H. (2005). Manajemen Kota. Yogyakarta: Pustaka Pelajar.

Yunus, S. H. (2010). Metodologi Penelitian Wilayah Kontemporer. Yogyakarta: Pustaka Pelajar. 